\title{
Análise Econômica da Racionalidade do Acordo de Colaboração Premiada
}

\author{
Economic Analysis of the Rationality \\ of the Collaboration Agreement
}

\section{Tiago Kalkmann ${ }^{1}$}

Universidade Federal do Rio Grande do Sul - Porto Alegre/RS

tiagokalkmann@gmail.com

http://lattes.cnpq.br/8527244412088630

https://orcid.org/0000-0003-1744-7311

Resumo: Este artigo pretende questionar se o acordo de colaboração premiada, previsto no art. $4^{\circ}$ da Lei $n^{\circ} 12.850 / 2013$, é uma decisão economicamente racional sob o ponto de vista do acusado colaborador. Para essa finalidade, serão expostos os elementos constituintes do acordo de colaboração premiada, demonstrando que sua instauração no sistema penal brasileiro ocorreu em um contexto de urgência pela resposta penal e de ineficiência dos instrumentos tradicionais de investigação. Em seguida, será utilizada a metodologia da análise econômica do direito para examinar a racionalidade da decisão do acusado de colaborar com as investigações. O trabalho conclui que a decisão de colaborar com as investigações não constitui escolha racional de acordo com os pressupostos da economia neoclássica. Partindo dos substratos da economia comportamental, verifica-se que a decisão é influenciada por vieses cognitivos causados por assimetria de informações entre acusação e defesa e pela utilização da prisão cautelar como forma de alteração da perspectiva do acusado. Dessa forma, o sistema conduz à utilização irracional da colaboração, que precisa ser equilibrada com outros instrumentos jurídicos indutores de comportamento.

Palavras-chave: Colaboração Premiada; Racionalidade; Viés Cognitivo; Heurística; Assimetria de Informações.

1 Mestre em Direito pela Universidade Federal do Rio Grande do Sul (UFRGS). Editor da Revista de Direito Penal e Política Criminal da UFRGS. 
ABSTRACT: This article questions whether the criminal collaboration, as on the article 4 from Law ${ }^{\circ} 12.850 / 2013$, is an economically rational decision to the defendant. In order to that, firstly, will be discussed the essential elements of the collaboration plea agreement, proving that its implantation in Brazilian's criminal justice system took place in the center of demands for punishment and inefficiency of the traditional investigation methods. Using the methodology of law and economics, this research quarrels the rationality of the decision to collaborate with the investigations. The work recognizes that this decision is not rational under the premises of the neoclassical economy. Thus, by the outlines provided by the behavioural economy, it's verifiable that this choice is influenced by cognitive biases, branched mostly from the informational asymmetry and the exceeding application of pre-trial detention to distort defendant's trial projection. In conclusion, the system leads to an irrational use of collaboration plea, that needs to be offset by other legal tools as a mean to induct behaviours.

Keywords: Plea agreement; Rationality; Cognitive bias; Heuristic; Informational asymmetry.

SumÁRIO: Introdução. 1. A Colaboração Premiada. 1.1. A Validade da Colaboração Premiada. 2. Avaliação Econômica da Racionalidade do Acordo. 2.1. Manifestação economicamente racional. 2.2. A manifestação da vontade na colaboração. 2.3. Os desvios de racionalidade do acordo. Conclusões. Referências.

\section{INTRODUÇÃo}

O trabalho em tela busca trazer o enfoque econômico para o exame da colaboração premiada no contexto brasileiro, em especial na análise da voluntariedade enquanto requisito de validade do acordo de colaboração.

Para esta finalidade, serão aplicados os instrumentos de law and economics (análise econômica do direito) à verificação das condições da manifestação de vontade do colaborador, questionando em que medida, na realidade, a decisão do acusado de colaborar com as investigações pode ser considerada uma decisão racional e eficiente do ponto de vista econômico. Por outro lado, verificar-se-á se a negativa de colaborar e o 
prosseguimento ao julgamento "comum" poderia ou não acrescer vantagens econômicas à situação jurídica do acusado, que poderiam chegar até mesmo à absolvição por ausência de provas.

A análise econômica do direito não importa em um novo objeto da análise, mas na aplicação da metodologia econômica ao universo do direito. Portanto, os institutos jurídicos são analisados sob a relação custo -benefício, ou seja, qualquer ato jurídico envolve a alocação de recursos em um ambiente de escassez ${ }^{2}$. A análise econômica do direito pode ser considerada consequencialista e utilitarista, focada nos benefícios que podem ser alcançados com o menor custo possível.

O instrumento de análise se expandiu na academia norte-americana, encontrando um amplo espaço de desenvolvimento. A economia passou a propor instrumentos para prever a forma como os comportamentos dos indivíduos serão afetados pela legislação (COOTER, ULEN, 2012, p. 2-9), propondo análise das normas jurídicas mediante os primados da eficiência e da distribuição ${ }^{3}$.

A economia passa a demonstrar como a lei é um "preço", ou seja, a regulação de determinado tema é sempre uma vantagem ou desvantagem levada em conta pelos indivíduos ao tomarem determinada decisão. Os contratos, sob a ótica econômica, são barganhas entre indivíduos, em que cada um busca a maximização de seu interesse; o direito, ao impor condições, é um preço a ser arcado pelas partes (POSNER, 2010, p. 20-27). No direito penal, a pena imposta pela lei é um custo sopesado pelo indivíduo com as vantagens que derivam da conduta criminosa ${ }^{4}$ (BECKER, 1974, p. 7-10).

2 COOTER e ULEN (2012, p. 1) destacam que até 1960, aproximadamente, o uso da economia no direito se resumia à legislação antitruste e à regulação do mercado. Após, seu uso foi se expandindo para outras áreas mais tradicionais, como o direito civil, constitucional e até mesmo penal. No âmbito da análise econômica do direito penal, passaram a ser feitas diversas perguntas, como o grau de eficiência das punições mais severas como instrumento de prevenção geral, por exemplo.

3 A análise econômica não ignora a influência de outros fatores nas condutas dos indivíduos, em especial dos valores e das normas morais. Todavia, tais discussões estão fora do direito e da economia, adentrando o campo da política ou da cultura.

4 Robert COOTER e Thomas ULEN (2012, p. 463) destacam que o criminoso é uma pessoa que age racionalmente, calculando os custos e vantagens da 
Contudo, a própria teoria econômica diverge acerca da forma como devem ser analisadas as condutas individuais, surgindo diversas escolas que buscam explicar o comportamento do ser humano em escassez de recursos.

A Escola de Chicago fundamenta-se nos postulados da economia neoclássica e foi desenvolvida sobretudo pelos trabalhos de Richard Posner e Ronald Coase. Segundo os pressupostos deste modelo, o indivíduo agirá sempre de maneira racional, buscando aquilo que lhe trará maior vantagem com menor uso de recursos (eficiência econômica). Para parte dos teóricos desta corrente (dentre eles Richard Posner), a própria análise econômica do direito só existiria pela aplicação dos primados da microeconomia clássica (AGUIAR, 2013).

A Behavioral Law and Economics, que possui em Cass SUNSTEIN (2008) um dos maiores expoentes, questiona alguns pressupostos da Escola de Chicago e da economia clássica. Afirma que os indivíduos nem sempre vão buscar apenas os próprios interesses de maneira egoísta ${ }^{5}$. Ademais, por vezes a racionalidade e o poder de escolha dos indivíduos são limitados ${ }^{6}$, fazendo com que a conduta efetivamente tomada não seja, necessariamente, maximizadora do seu bem-estar ${ }^{7}$. Contudo,

atividade; além disso, é uma pessoa amoral, pois é movido à atividade criminosa pela simples perspectiva de vantagem sem deixar-se crivar por culpa ou moralidade.

5 Na realidade, a escola behaviorista, ao introduzir elementos comportamentais na análise econômica, não busca substituir o paradigma neoclássico da Escola de Chicago (BAR-GILL, EPSTEIN, 2007, p. 1-5). A ideia é de aprimorar a aplicação da microeconomia, com o acréscimo de novos elementos, sem excluir os pressupostos da eficiência e da maximização das vantagens da teoria econômica.

6 Na realidade, propõe que as decisões são tomadas não apenas com base na racionalidade, mas também em heurísticas, que são considerados atalhos à racionalidade que aceleram o processo de tomada de decisão, embora às vezes haja desvio da racionalidade comum (KOROBKIN, ULLEN, 2000, p. 2627). Uma das principais heurísticas seria o processo da chamada "cascata de disponibilidade”, exposta por KURAN e SUNSTEIN (1999, p. 34-36). Voltaremos às heurísticas em momento posterior.

7 BAR-GILL e HAREL (2001, p. 6-12), estudiosos da corrente behaviorista, defendem que o simples aumento da pena, considerado pela teoria neoclássica como um indutor da redução da criminalidade, não possui todo este poder de prevenção do crime. Segundo os autores, o criminoso nem sempre age da 
outros autores afirmam que a teoria behaviorista nada traz de novo, pois a teoria neoclássica já traria, em si, a flexibilidade necessária para acolher os argumentos relacionados a heurísticas e indisponibilidade de informações (WRIGHT, 2007, p. 2-6).

O debate entre os pressupostos destes dois modelos de análise ${ }^{8}$ é essencial para o deslinde do tema deste artigo. Como se pretende demonstrar, o acordo de colaboração premiada nem sempre é resultado de manifestação racional do colaborador.

Na primeira parte, serão definidos os contornos institucionais da colaboração premiada, bem como seu surgimento em um contexto de emergência e de deficiência na produção da prova. Em seguida, serão definidos os seus requisitos fundamentais e o que se entende por manifestação voluntária para fins de acordo processual.

Na segunda parte, será avaliada economicamente a voluntariedade do colaborador, expondo as diferenças na racionalidade da manifestação de vontade segundo as escolas neoclássica e behaviorista. Em especial, serão expostos os elementos relacionados à chamada "teoria dos jogos", que busca explicar a tomada de decisão do acusado por colaborar e não ir a julgamento. Por fim, será demonstrado como a voluntariedade no acordo de colaboração está assentada em acentuada assimetria de informações e uso exacerbado da prisão preventiva, que retiram a natureza racional da opção.

Por fim, serão demonstradas estratégias, como a manutenção da liberdade do colaborador e o reequilíbrio da assimetria de informações entre acusador e acusado, que podem auxiliar na reinserção de racionalidade no sistema.

maneira racional como prega a teoria neoclássica, sendo que muitas vezes subestima os riscos de punição.

8 Existem inúmeros outros modelos de análise econômica, cada um com suas particularidades. Podem ser citados os modelos da Public Choice Theory, exemplificada pelo trabalho de MCNUTT (2002) e portadora de análise relevante do ponto de vista da manifestação política, bem como da New Haven, que propõe análise como foco no Estado Social, exemplificada pelos trabalhos de Guido CALABRESI (2008). Para as finalidades deste artigo, contudo, as escolas com maiores contribuições são a neoclássica e a behaviorista, razão pela qual são tratadas com particularidade. 


\section{A Colaboração Premiada}

A colaboração premiada é um instrumento de justiça negociada (VASCONCELOS, 2014, p. 229) que consiste em um acordo por meio do qual um acusado ou investigado se compromete com o órgão acusatório a colaborar com as investigações e receber do Estado um prêmio pelo auxílio prestado.

Trata-se de instituto muito utilizado pela justiça italiana como forma de obter provas para desmantelar as máfias (FONSECA, 2017, p. 74-83), principalmente pela figura dos pentiti - que poderia ser traduzido como arrependidos -, que se "arrependem" da prática criminosa e passam a auxiliar as investigações, delatando seus comparsas.

É, na realidade, um instituto processual com reflexos no direito material'. O Supremo Tribunal Federal já teve a oportunidade de se manifestar sobre a sua natureza jurídica, asseverando que se trata de instrumento de obtenção de prova ${ }^{10}$, o que exclui a concepção de que a colaboração, por si só, seria meio de prova ${ }^{11}$. Entretanto, não se pode concordar com a visão reducionista da Corte, pois esta definição ignora os reflexos materiais da colaboração, como a redução da pena e até mesmo a extinção da punibilidade.

A colaboração premiada encontra-se atualmente regulamentada no art. $4^{\mathrm{o}}$ da Lei $\mathrm{n}^{\mathrm{o}} 12.850 / 2013^{12}$, com a previsão de prêmios e formas de

9 Destaca PEREIRA (2013, p. 36-41) que a delação, que ele chama de arrependimento processual, se diferencia do arrependimento material ou substantivo. Este último englobaria os casos em que o agente encerra a conduta típica ou age para evitar seus efeitos, e tem para si um prêmio para esta conduta. Seriam os conhecidos casos de arrependimento eficaz ou desistência voluntária. A delação ocorreria em momento posterior, processual, em que o acusado confessaria seus crimes e auxiliaria as autoridades.

10 Veja-se, a este respeito, a decisão proferida pelo Ministro Dias Toffoli na Questão de Ordem no Inquérito $\mathrm{n}^{\circ} 4.130$.

11 A diferença consiste, basicamente, em que a colaboração não é prova, mas um instrumento utilizado para se obter as provas. Portanto, nunca poderá haver uma decisão condenatória proferida exclusivamente com fundamento em colaboração premiada; também não poderia, em teoria, haver a decretação de prisão preventiva com esse fundamento. A colaboração necessita da chamada prova corroborativa, ou seja, uma prova validamente produzida que venha a corroborar ou confirmar as informações advindas do acordo.

12 Na realidade, a previsão legal da chamada delação premiada remonta a 1990, com a promulgação da Lei de Crimes Hediondos. A referida legislação passou 
colaboração. Todavia, essa diversidade apenas torna mais difícil determinar a natureza jurídica da colaboração e a justificativa para a concessão do prêmio ao colaborador. Alguns buscam justificar o prêmio sob a ótica dos fins da pena e da prevenção geral e especial (BITTAR, 2011, p. 76-86). Contudo é extremamente questionável em que medida o colaborador apresenta-se menos culpável ou a presença do instituto é capaz de inibir a prática criminosa.

Na realidade, a colaboração premiada possui mista, pois apresenta tanto efeitos processuais quanto materiais. A raiz político-criminal do instituto no ordenamento jurídico brasileiro remonta à incursão de ideias do movimento law and $\operatorname{order}^{13}$ (BRITO, 2017, p. 46-54), marcado pelo medo social difuso e a emergência do Estado na apresentação de punições concretas. Tal situação justifica a adoção de novas medidas chamas de "processo penal de emergência" ${ }^{14}$, marcado pela adoção de medidas excepcionais supostamente justificadas por uma situação emergencial (CHOUKR, 2002, p. 6), que muitas vezes sequer existe. Não é mera coincidência o que se desenvolve no interior da Operação Lava-Jato.

Na linha do que assentam MORAIS e BONACCORSI (2016), a luta contra a corrupção constitui o novo mote atribuído ao processo penal, ou seja, a situação emergencial que demanda atuação rápida. A premência de tal "guerra" justifica o uso de medidas excepcionais ou emergenciais:

O direito penal e o processo penal no âmbito dos crimes econômicos e do novo perfil criminógeno foi se encaminhando para

a prever a redução da pena para o criminoso que delatasse seus comparsas no crime de extorsão mediante sequestro. Aos poucos, o instituto foi se expandindo, passando a ser previsto em diversas regulações. A respeito desse histórico, deve-se consultar BITTAR (2011, p. 89-158). Todavia, a expressa garantia de direitos básicos ao colaborador e aos delatados só passou a ser prevista na Lei 12.850, como o procedimento mínimo para a gestão do instituto. Lembre-se que a implantação da delação premiada no Brasil ocorreu com a Lei de Crimes Hediondos, expoente do movimento Law and Order. Trata-se de um movimento que reduz o crime a uma questão de polícia (BELLI, 2003, p. 58-64), com aumento excessivo de policiamento, recrudescimento das penas e o desenvolvimento de mecanismos de resolução rápida dos crimes.

O processo penal de emergência é a contrapartida processual do direito penal do inimigo. Segundo esta corrente processual, a sociedade está assolada por inimigos do povo, que demandam uma intervenção enérgica e excepcional do estado na condução das investigações. 
uma aproximação com a luta contra o narcotráfico, depois com a luta contra o terror para agora se apoiar em uma luta contra a corrupção. Para viabilizar esse fim político se apoiou em um processo penal contaminado pelo emergencialismo penal, voltado para uma resposta imediata e cautelar, vinculada a prisões processuais e outras fórmulas invasivas de investigação e por outro lado, em um direito premial, que usa a colaboração como possibilidade de esclarecimento efetivo (MORAIS, BONACCORSI, 2016, p. 98).

A colaboração premiada é um entre vários instrumentos transpostos de sistemas jurídicos exógenos com o objetivo de facilitar a condução das investigações e obter as provas necessárias à persecução penal de maneira rápida para atender aos anseios punitivistas.

Justamente por isso é que se pode dizer que a colaboração é o atestado de óbito da capacidade investigativa estatal. A colaboração premiada implica esvaziamento do ônus probatório imposto à acusação, que deixa de ser responsável por produzir as provas incriminatórias e impõe ao acusado a carga de sua condenação ${ }^{15}$ (VASCONCELLOS, 2017, p. 268).

Frente a uma demanda crescente por punição - especialmente no âmbito da criminalidade organizada e de colarinho branco - e a incapacidade dos órgãos de obter provas por outros meios ${ }^{16}$ (SILVA, 2017, p. 290-293), faz-se uso do referido instrumento com frequência assustadora.

O uso da colaboração premiada com a montagem de shows televisivos transmite a sensação de segurança e aplaca a cultura de emergência (MENDES, BARBOSA, 2016, p. 73). Surgem nesse contexto os

15 Como tentativa de reduzir os riscos e os danos associados aos mecanismos negociais, especialmente decorrentes da inversão do regime acusatório, a Lei $\mathrm{n}^{\circ} 12.850 / 2013$ assegura que os elementos não podem ser utilizados exclusivamente em seu desfavor. Da mesma forma, não podem ser utilizados para a condenação do próprio delator (VASCONCELLOS, 2017, p. 269).

16 Uma das razões para a verificada disfuncionalidade probatória está na estrutura dos delitos que se pretende investigar. A corrupção administrativa organizada apresenta um modus operandi complexo, normalmente por meios tecnológicos sofisticados, autoria mediata (Hintermann), conexão entre organizações diversas e imersão no aparato estatal (SILVA, 2017, p. 288-289). 
paladinos da paz social e os aurores da justiça, ovacionados pela adoção de medidas de urgência ${ }^{17}$.

Diante de um estado incapacitado, a supremacia é dos instrumentos investigativos que necessitam de menor esforço, trazendo resultados rápidos ao custo da preservação de garantias processuais. De outra forma, o Estado simplesmente não seria capaz de investigar a criminalidade organizada e de colarinho branco ${ }^{18}$. A colaboração perdeu seu caráter excepcional e assumiu o papel de protagonista das investigações (SILVA, 2017, p. 290).

\subsection{A Validade da Colaboração Premiada}

Ultrapassando a justificativa do instituto e a análise do seu contexto de surgimento, passa-se ao exame dogmático do instituto, conforme implantado pela Lei $\mathrm{n}^{\circ} 12.850 / 2013$.

Nos termos do art. $4^{\circ}$ da referida lei, a colaboração deve ser voluntária, alcançar algum dos resultados legalmente descritos, a renúncia do direito ao silêncio (§ 14) e a presença de advogado do colaborador (§ 15). A doutrina indica como requisito obrigatório a confissão do colaborador, ou seja, este deve ser partícipe ou coautor da conduta e confessar a sua prática ${ }^{19}$ (BITTAR, 2011, p. 168-172).

17 Engana-se quem pensa que tais ações espetacularizadas incontestadamente reduzem a criminalidade: BELLI (2003, p. 58-64) contesta os dados do movimento Tolerância Zero nos Estados Unidos, indicando que as taxas de diminuição da criminalidade já eram decrescentes quando as medidas foram efetivamente implantadas. Aliás, aponta que outras medidas menos invasivas geraram taxas de diminuição ainda maior, como o policiamento comunitário implantado em San Diego.

18 CHOUKR (2002, p. 45-52) alerta que o fenômeno emergencial deixa suas marcas principalmente no campo probatório. Este movimento acomodativo leva à involução das técnicas investigativas dos órgãos policiais e a não diversificação dos instrumentos probatórios.

19 A confissão é considerada como pressuposto lógica da possibilidade de colaborar. De outra forma, entende a doutrina que a colaboração de alguém que não é coautor ou partícipe é infrutífera. A precedência lógica, contudo, não é dogma inquestionável; deve-se levar em conta, por exemplo, a existência da chamada Alford Guilty Plea no sistema norte-americano, em que o acusado pode negociar com a acusação sem que precise assumir a culpa por qualquer ato. Aliás, a 
Colocar a confissão como elemento preliminar da delação reforça seu caráter de mero instrumento de obtenção do maior número de culpáveis possível para impulsionar a máquina acusatória. Inaugura-se um novo regime de verdade no processo penal que, apesar disso, não abandona a confissão como eixo fundante do sistema penal desde o século XVIII (AMARAL, GLOECKNER, 2017, p. 72-73).

Com relação à renúncia ao direito ao silêncio, verifica-se a existência de enorme paradoxo, pois é impossível manter-se plenamente o direito fundamental à não autoincriminação e ao mesmo tempo celebrar acordo (BRITO, 2017, p. 74-83). Por essa razão, deve-se ter muito cuidado com a extensão de tal exigência. Mantenha-se em mente que o silêncio constitui direito constitucional fundamental (art. $5^{\circ}$, LXIII, da Constituição Federal) e são descabidas quaisquer exigências de renúncia genérica de direito, bem como renúncia ao silêncio que ultrapasse os limites dos fatos investigados ${ }^{20}$.

A efetividade da colaboração, enquanto requisito de sua validade, implica em afirmar que o colaborador não será apenas mais uma testemunha no processo, mas deve colaborar ativamente com as investigações dos fatos (LIMA, 2013, p. 793-795). Condicionar a validade da colaboração à sua efetividade constitui erro do legislador, pois submete a concessão do prêmio à forma como o Estado atuará em posse das informações concedidas. Em outras palavras, caso o Estado receba as informações, mas se omita, a colaboração poderia ser considerada inválida ${ }^{21}$.

A lei propõe cinco resultados que devem derivar da colaboração do acusado: a) a identificação dos demais coautores e partícipes da organização

exigência da confissão revela-se descabida, uma vez que em nosso sistema ela só encontra validade quando confirmada pelos demais elementos de prova.

20 A maneira mais adequada de analisar esta renúncia, do ponto de vista constitucional, é aplica-la a cada informação revelada pelo colaborador, devendo ser mantida a possibilidade de se negar a revelar qualquer informação que entende irrelevante ou despropositada. O prêmio será devido de acordo com a intensidade da colaboração do acusado (BITTAR, 2011, p. 181-187).

21 A exigência da condenação dos coautores poderia significar o condicionamento do prêmio do colaborador a variáveis até mesmo de natureza processual, como a prescrição ou a defesa técnica (PEREIRA, 2013, p. 154-173). Felizmente, a legislação brasileira não inclui a necessidade de condenação dos coautores como requisito de eficácia da colaboração. 
e as infrações por ele praticadas ${ }^{22}$; b) revelação da estrutura hierárquica e divisão de tarefas da organização criminosa; c) prevenção de infrações penais $^{23}$; d) recuperação total ou parcial do produto das infrações; ou e) localização de eventual vítima com a integridade física preservada ${ }^{24}$.

Todavia, o requisito de validade mais importante para este estudo é a voluntariedade do acordo e das informações prestadas, para fins de verificação do grau de racionalidade dessa suposta manifestação voluntária.

A doutrina tradicional indica que a voluntariedade se verifica quando o acordo é também desejado pelo colaborador, ou seja, não foi forçado de nenhuma forma (PEREIRA, 2013, p. 132). Este requisito, por si só, já não é facilmente verificável. O colaborador normalmente encontrase em situação de vulnerabilidade quando firma o acordo com a acusação, seja física, psicológica ou informacional, ou seja, em desigualdade sobre o conhecimento das informações até então existentes sobre o caso. AIRES e FERNANDES (2017, p. 266) destacam que a tentativa de assegurar a voluntariedade justificou a adoção de diversos mecanismos legais, como a obrigatória assistência do defensor e a homologação judicial, por exemplo. Apesar disso, tais mecanismos não são suficientes para assegurar a real vontade do colaborador, tendo em vista as diversas vulnerabilidades a que se encontra submetido.

Do ponto de vista físico, deve-se destacar que é extremamente comum que o colaborador esteja preso cautelarmente antes ou depois de firmar o acordo. Alguns acordos negociam até mesmo a duração da prisão cautelar (BOTTINO, 2016, p. 360-366). Sob o prisma psicológico, muitas vezes o acusado se vê premido a colaborar sob a ameaça constante de condenação ou decretação de prisão.

Do ponto de vista informacional, o acusado encontra-se vulnerável por não entender até que ponto a acusação detém elementos de prova

22 Este é o conhecido caso da "delação premiada”, ou seja, o colaborador identifica os demais agentes da prática criminosa em troca de prêmio. É a forma mais tradicional de colaboração e a primeira a ser implantada em nossa legislação.

23 Nesta modalidade, a colaboração seria justificada, dogmaticamente, pela prevenção especial, ou seja, evitar que determinados agentes levem à cabo a prática delitiva.

${ }^{24}$ Não é demais frisar que tais resultados são alternativos, ou seja, não se exige que a colaboração leve a todos os resultados supracitados. 
que podem condená-lo ${ }^{25}$, prejudicando a escolha entre colaborar ou ser processado. A questão se afigura relevante pelo fato de que o investigado ou acusado opta por não ir a julgamento sem conhecer propriamente as consequências de sua escolha, ou seja, sem saber se a acusação possui ou não elementos de condenação.

A doutrina ainda estuda a influência da informação (ou da falta dela) na formação da vontade do acordo (COSTA, 2017, p. 157-161). No âmbito do direito privado, a manipulação ou ocultação de informações para obter determinado acordo pode acarretar a anulabilidade do negócio jurídico, caso se verifiquem as hipóteses de dolo (arts. 145 a 150 do Código Civil). No direito do consumidor, a vulnerabilidade informacional é tratada com maior profundidade, sendo a obtenção de todas as informações relativas a produto ou serviço alçada à categoria de direito básico do consumidor contratante (art. $6^{\circ}$, inciso III, e art. 46, do Código de Defesa do Consumidor).

Se partirmos do pressuposto de que a voluntariedade significa que o acordante desejou o resultado, não se pode afirmar seguramente tal vontade quando o acusado não conhece todas consequências da decisão de firmar ou de não firmar o acordo. A teoria econômica revela que decisões tomadas com vulnerabilidade de informações efetivamente ignoram os resultados desvantajosos que podem ser causados, lançando uma nova luz à análise da voluntariedade do ponto de vista da racionalidade econômica.

\section{Avaliação Econômica da Racionalidade do Acordo}

Nesse capítulo, pretende-se analisar, segundo os parâmetros da economia behaviorista, se a decisão de colaborar com as investigações pode ser considerada perfeitamente racional. Para essa finalidade, primeiramente será feita uma comparação entre a manifestação

\footnotetext{
25 Na realidade, a vulnerabilidade informacional só faz sentido do ponto de vista econômico e sob o prisma da teoria dos jogos. Por essa lente, a vulnerabilidade informacional revela que o colaborador possui menores condições de tomar decisões racionais, fazendo com que adote estratégias contrárias aos seus interesses. $\mathrm{O}$ assunto será mais bem desenvolvido nos pontos 2.2 e 2.3 , infra.
} 
de vontade para a economia neoclássica e os aportes oferecidos pela economia comportamental.

Em seguida, buscar-se-á compreender de que forma a colaboração processual é analisada pela teoria econômica, considerando o acordo processual como uma conduta estratégica nos moldes propostos pela teoria dos jogos.

Por fim, demonstraremos como os instrumentos oferecidos pela teoria dos jogos e pela economia comportamental denotam a possibilidade de que a colaboração venha a ser considerada uma decisão irracional por parte do réu, não contribuindo para a maximização das vantagens que podem resultar da condução do processo.

\subsection{MANifestaÇão eCONOMICAMENTE RACIONAL}

Com os estudos elaborados por Richard Posner (1985), entendeu-se ser possível a realização de uma análise econômica para qualquer ramo do direito, utilizando-se o método da escolha racional para uma alocação eficiente de recursos. Ou seja, qualquer decisão (divorciar-se, cometer determinado crime, firmar um contrato, ou, até mesmo, firmar um acordo de colaboração premiada) pode ser analisada sob a ótica de uma escolha que maximize a utilidade de quem decide, desde que ele o faça premido por racionalidade ${ }^{26}$. Assim, tudo se torna passível de ser estudado pela economia: o divórcio será uma escolha racional se trouxer utilidade ao cônjuge, e assim por diante.

O “Ótimo de Pareto" (COOTER, ULEN, 2012, p. 14), segundo a visão clássica, é a situação em que as condutas racionais geram aumento de utilidade para todos os agentes. A decisão racional e voluntária de firmar contrato, por exemplo, pode se demonstrar um ótimo de Pareto, quando trouxer vantagens para todos os envolvidos ${ }^{27}$.

26 A maximização da utilidade é o guia para se aferir a racionalidade, considerados estes parâmetros. A conduta humana racional sempre maximizará a utilidade ou trará vantagens ao agente, ainda que não seja uma vantagem necessariamente econômica.

27 O equilíbrio de Pareto possui sua utilidade muito questionada, uma vez que descreve uma situação ideal de pouca verificabilidade prática. Em razão 
Por óbvio, tais preceitos são aplicáveis à decisão de se cometer um crime. Segundo Gary BECKER (1974, p. 1-2), os indivíduos fazem escolhas racionais para cometerem ou não crimes, baseadas no cálculo probabilístico de vantagens e custos. Entre as vantagens, existe o proveito imediato do crime, enquanto entre os custos há a probabilidade de ser processado e punido pela conduta ${ }^{28}$. Com o instrumento probatório da colaboração premiada, os crimes de corrupção tornam-se mais facilmente elucidáveis, como já explanado anteriormente, gerando esperanças do incremente do papel preventivo geral da pena para a criminalidade de colarinho branco, haja vista que, para a escolha pela prática da conduta corrupta, tal fator (maior facilidade de elucidação) passaria a ser considerado pelo sujeito racional no cálculo dos custos e dos benefícios (dentro da equação elaborada por Gary Becker), levando em conta a probabilidade dos autores destes crimes serem identificados e punidos. Aliás, qualquer meio eficiente de investigação poderia ser considerado, perante o parâmetro econômico, um instrumento de prevenção geral.

A contraposição que se faz à teoria do comportamento racional deriva de ordem social e psicológica. Como bem lembra Geraldo BRENNER (2009, p. 72-75), alguns crimes serão cometidos, ainda que a punição seja severa ${ }^{29}$. São vários os casos em que por emoção, irracionalidade, desconhecimento e até mesmo descuido pessoas cometem crimes. Como é que se poderia explicar o cometimento de um crime em que o agente

destas críticas, várias outras formas de equilíbrio econômico foram propostas. Um exemplo é o Equilíbrio de Kaldor-Hicks (COOTER, ULEN, 2012, p. 14), em que as decisões serão economicamente racionais e trarão equilíbrio desde que a soma de todas as vantagens geradas supere as desvantagens. Dessa forma, ainda que um agente sofra apenas desvantagens, pode se verificar uma situação de equilíbrio desde que as vantagens dos demais agentes (ou de um deles) supere as perdas dos demais.

Nem todos os seres humanos racionais, quando postos em determinadas situações, irão efetivamente cometer crimes, uma vez que a própria economia não é cega à existência de valores que guiam a conduta individual. Para dar uma resposta a essa situação a Teoria Econômica classifica o criminoso como um ser racional e amoral.

29 A probabilidade de ser punido é um custo analisado pelo criminoso, segundo a posição clássica e conforme a equação de Gary Becker (1974, p.7-9). Dessa forma, quanto maior a punição maior é o custo da conduta criminosa, razão pela qual se poderia imaginar que punições severas sempre evitariam crimes. 
certamente será submetido a uma pena grave? Como é que se explicam os dados (já apontados) que demonstram até mesmo o crescimento de determinados tipos de criminalidade mesmo com o incremento da pena? GONÇALVES (2015, p. 80) afirma que os crimes desprovidos de razão ou com racionalidade reduzida não são alvos da análise econômica. Ao contrário do afirmado pelo autor, tais situações são objeto da análise econômica behaviorista.

A economia behaviorista assevera que o indivíduo nem sempre apresenta processo perfeitamente racional de tomada de decisões, mas que comete erros sistemáticos com base em heurísticas ou atalhos de racionalidade. As formulações da economia comportamental buscam demonstrar que indivíduos não erram aleatoriamente, mas sistematicamente, apresentando desvio do padrão de comportamento previsto e descrito pela economia neoclássica (ULEN, MCADAMS, 2008, p. 4-5). Para os fins deste trabalho, os desvios mais importantes são os desvios da perfeita racionalidade ${ }^{30}$.

O ser humano nem sempre toma todas as suas decisões com base em avaliações de custos e benefícios. Muitas decisões são baseadas em heurísticas, que nada mais são do que atalhos utilizados no processo de tomada de decisão que podem levar a um resultado diverso daquele que seria considerado economicamente eficiente ${ }^{31}$.

Estudos empíricos (ULEN, MCADAMS, 2008, p. 9-10) indicam que os indivíduos tendem a sobrestimar a incidência e a relevância de eventos memoráveis ou famosos, ainda que em contrariedade aos fatos. É a chamada heurística da disponibilidade. KAHNEMAN (2011, p. 106-112) define a disponibilidade como o processo de julgar a frequência de um evento pela facilidade com que ele vem à mente. Se os eventos memoráveis

30 Os autores apontam que o comportamento do ser humano não desvia apenas da racionalidade proposta pela economia neoclássica, mas também de diversos outros pressupostos daquele paradigma. Assim, existem também desvios da conduta egoísta (como no caso de doação pura ou assistência social), do autocontrole (como no caso dos vícios) e também da conduta utilitária (ULEN, MCADAMS, 2008, p. 6-7).

31 Na verdade, a utilização de atalhos de raciocínio na maioria das vezes leva a resultados eficientes, pois o fundamento dos atalhos é, majoritariamente, resultado de experiências verdadeiras. Contudo, muitas vezes a decisão é orientada por atalho que não conduz à maximização das vantagens que era esperada. 
o são justamente por serem mais comuns, este atalho mental pode levar a estimativas de frequência próximas da realidade; todavia, podem ser memoráveis por diversos outros motivos além de uma ocorrência frequente. Christine JOLLS (2004, p. 11) acrescenta que a disponibilidade influencia a decisão de cometer infração. O cálculo da probabilidade de punição não depende apenas da frequência com que são descobertos os crimes, mas também de métodos vívidos e escandalosos de detecção ${ }^{32}$.

Em sequência à heurística da disponibilidade ${ }^{33}$, verifica-se o viés da projeção, segundo o qual os agentes possuem a tendência de superestimar a quantidade de pessoas que agem da mesma forma. Portanto, é tendência imaginar que diversas outras pessoas cometem o mesmo crime, por exemplo, e não são presas $^{34}$.

Deve ser feita, ainda, referência aos chamados "descontos hiperbólicos”, na linha noticiada por ULEN e MCADAMS (2008, p. 22-24). Os autores indicam que os agentes, no momento da escolha, tendem a preferir retornos menores e antecipados a retornos maiores e posteriores, desde que a vantagem menor seja quase imediata ${ }^{35}$. Portanto, grandes ofertas momentâneas atraem mais do que ganhos de longo prazo.

32 A autora cita o exemplo de infrações de trânsito. Segundo os estudos, a utilização de tíquetes de multa de cor laranja para casos de estacionamento ilegal aumenta a visibilidade da punição e são mais fáceis de trazer à memória. Dessa forma, apresenta um efeito preventivo maior e auxilia na diminuição das infrações, ainda que o número de multas aplicadas venha a ser efetivamente reduzido (JOLLS, 2004, p. 11).

ULEN e MCADAMS (2008, p. 19) denotam que a "projeção" pode ser uma decorrência direta da heurística da disponibilidade, como nos casos em que o indivíduo se associa com pessoas que pensa e age de forma semelhante. Assim, é mais fácil retomar à memória indivíduos que pensam e agem da mesma forma. Todavia, os autores reiteram que não há uma imbricação necessária entre os dois.

O viés da projeção tem relação com as chamadas teorias da adequação social da conduta: uma conduta deve deixar de ser criminosa quando houver ampla aceitação social. Todavia, o agente superestima a ocorrência de tais crimes e a forma como são aceitos por seus pares, podendo gerar controvérsias acerca da culpabilidade de indivíduo que age sob o pretexto de um consenso social inexistente.

Os autores anotam que se ambos retornos forem relativamente distantes, o indivíduo preferirá o retorno maior ainda que seja de longo prazo. Dessa forma, para manipular decisões com base nesta heurística, basta o oferecimento de descontos gigantes para o momento, fazendo com que a proposta seja 
Além disso, aponta GAROUPA (2003, p. 9) que indivíduos tendem a ser otimistas acerca de suas habilidades e superestimar os lucros que podem derivar da prática criminosa. É a chamada "propensão otimista”, que diz respeito também à minimização das chances de ser preso ou condenado. O criminoso otimista comete mais crimes do que aquele puramente racional: não são erros aleatórios, mas direcionados pela visão que o indivíduo possui de si mesmo. Assim, a prevenção criminosa demandaria maiores sanções ou então o desenvolvimento de formas de eliminar a referida propensão ao otimismo.

Intimamente relacionada à citada propensão é a "ilusão de controle". Diversas evidências psicológicas demonstram que indivíduos estimam sua capacidade de controlar os riscos e adversidades em um patamar superior à realidade (ULEN, MCADAMS, 2008, p. 20-21). De maneira semelhante, as propostas que se demonstram mais "controláveis" ou "maleáveis" são atrativas, ainda que tal perspectiva de controle não ofereça benefício real.

KAHNEMAN (2011, p. 218-219) aponta, por fim, que a escolha em situações de risco não ocorre da forma como prevista tradicionalmente pela teoria da utilidade. Segundo o autor, toda escolha que envolve riscos dependerá da adoção de um "ponto de referência" determinado. Por isso a "teoria da perspectiva" oferece melhor solução, fundamentada nos seguintes elementos: a) toda valoração de ganhos ou perdas depende do "nível de adaptação" ${ }^{36}$; b) a sensitividade às perdas é decrescente ${ }^{37}$; c) perdas são mais significantes do que ganhos, fazendo com que o indivíduo adote postura de aversão às perdas ${ }^{38}$.

quase "irrecusável”, ainda que a longo prazo os ganhos pudessem ser maiores em análise puramente racional.

Um exemplo deste princípio é a forma de adaptação ao clima, por exemplo. Uma pessoa que está em câmara fria e sai para os $25^{\circ}$ do ambiente externo sentirá calor, enquanto pessoa que sai de fornalha para o mesmo ambiente irá sentir frio, uma vez que o nível de adaptação de cada pessoa é completamente diverso.

37 Segundo essa perspectiva, aponta KAHNEMAN (2011, p. 357) que a diferença subjetiva entre 100 e 200 dólares é maior do que aquela entre 1.200 e 1.100 dólares, justamente em razão da diminuição da sensitividade às perdas. Da mesma forma, acender uma luz forte em uma sala escura é mais detectável do que a mesma luz em uma sala já amplamente iluminada.

38 Tome-se, como exemplo, uma decisão em um jogo. O indivíduo pode prosseguir apostando, com $50 \%$ de chance de ganhar 1000 reais, ou desistir e ficar 
Portanto, a perspectiva de perder funciona como um custo muito maior à prática criminosa do que a possibilidade de "deixar de ganhar" o objeto ou valor. A depender da forma como as opções são apresentadas ao criminoso, preso ou não, suas perspectivas são alteradas, podendo fazer com que tome decisões contrárias à pura utilidade racional.

\subsection{A MANIFESTAÇÃO DA VONTADE NA COLABORAÇÃO}

O acusado ou investigado no contexto de uma organização criminosa se vê dividido entre duas opções: a) firmar acordo com a acusação, abandonar a atividade criminosa e aceitar a pena proposta; ou b) prosseguir na atividade criminosa e correr o risco de ser investigado e, eventualmente, condenado. O desenvolvimento, contudo, não irá depender apenas de sua ação, mas de uma série de variáveis, que vão desde o teor do acordo proposto até a conduta dos demais membros da organização criminosa ${ }^{39}$.

A melhor forma de analisar a escolha do indivíduo se dá por meio da “teoria dos jogos”. Segundo PICKER (1994, p. 2-3), a teoria dos jogos é um conjunto de ferramentas e linguagens para descrever e prever comportamentos estratégicos. Em outras palavras, a teoria dos jogos é um modelo teórico que busca descrever as ações estratégicas adotadas pelas pessoas em contextos em que o resultado das ações depende também das ações de outros agentes. Segundo o autor, a teoria tem sua aplicação em todas as situações em que uma pessoa deve agir levando em conta a ação de outra pessoa ${ }^{40}$, a fim de montar a estratégia que aumenta sua utilidade considerando as variáveis de ação.

com 500. Nessa situação, aponta KAHNEMAN (2011, p. 225) que a maioria das pessoas fica com aquilo que é "certo". Por outro lado, se a perspectiva do jogo muda para a perda, a decisão mudará. Assim, em outro jogo, o indivíduo pode optar por uma "perda" certa de 500 reais ou jogar, com $50 \%$ da chance de perder 1000 reais ou de não perder qualquer valor. Nessa situação, a maioria das pessoas tem comportamento avesso às perdas, optando por jogar. Todavia, os valores envolvidos são exatamente os mesmos nos dois jogos, o que demandaria solução idêntica segundo a teoria da utilidade. Entretanto, a alteração de perspectiva de ganho para perda altera a matriz de comportamento.

Como se verá, o primeiro colaborador recebe mais incentivos pela lei. Portanto, o fato de nenhum membro da organização ter firmado acordo aumenta a utilidade, pois os prêmios prometidos pela lei são maiores.

40 Na realidade, o autor aponta que em praticamente todas as situações haverá mais de dois tomadores de decisão influenciando no jogo, tendo em vista as 
GONÇALVES (2015, p. 69) destaca que o conflito ocorre uma vez que todos os agentes buscam desenvolver estratégias para maximizar sua utilidade, mas sempre de acordo com as regras pré-estabelecidas. Existem vários tipos de jogos, cada um com suas peculiaridades. Os jogos podem ser simultâneos, quando todos os jogadores devem jogar ao mesmo tempo, desconhecendo a estratégia alheia, ou sequenciais, quando o jogador monta sua estratégia levando em conta a ação do jogador anterior.

A aplicabilidade da teoria dos jogos à colaboração premiada decorre de seu essencial teor interativo, que autoriza sua expansão às demais áreas do conhecimento em que se verifica a necessidade de interação entre agentes para o alcance dos resultados (VASCONCELLOS, 2006, p. 171-174).

O exemplo de jogo simultâneo citado pelos teóricos consiste no chamado dilema dos prisioneiros (PICKER, 1994, p. 3-6). Há uma situação em que dois indivíduos estão isoladamente presos e não podem se comunicar. A polícia oferece a chance a cada um deles de confessar e delatar o outro, em troca de diminuição da pena. Se nenhum confessar, a pena será menor, pois os investigadores não têm provas no momento. Todavia, se apenas um delatar e o outro não, este sofrerá pena muito mais grave. Nesta situação, a melhor opção para cada um dos prisioneiros é delatar, pois não pode suportar o risco de sofrer uma pena muito mais grave caso apenas o outro delate. Portanto, há a mesma estratégia dominante para ambos os jogadores ${ }^{41}$. Caso os jogadores (prisioneiros) efetivamente pudessem combinar suas jogadas, o melhor seria não confessar, tendo em vista as penas ainda menores que receberiam diante da ausência de provas.

Esta deve ser considerada a situação prática da colaboração premiada. Não se trata de jogo simultâneo; além disso, os agentes não estão isolados, sendo possível que combinem suas estratégias. O elemento

inúmeras variáveis e consequências de uma determinada ação em sociedade. Além disso, uma decisão possivelmente estará relacionada com uma próxima medida, montando uma estratégia de jogo sofisticada (PICKER, 1994, p. 12).

41 A estratégia dominante é aquela que oferece retornos maiores do que as estratégias alternativas. A estratégia dominada, por sua vez, oferece retornos menores que as outras alternativas. A presença de uma estratégia dominante soluciona o jogo, pois é a melhor opção para o jogador segundo a teoria da utilidade. 
cooperativo é inserido na teoria dos jogos por John Nash, que propôs nova forma de equilíbrio dentro da teoria dos jogos (FIANI, 2009, p. 93-109).

Segundo Nash (FIANI, 2009, p. 93-109), a cooperação dentro do jogo é compatível com o objetivo de ganho individual, ou seja, os ganhos individuais são maximizados mediante a cooperação com o adversário ${ }^{42}$. O equilíbrio de Nash ocorre justamente quando cada jogador está satisfeito com a sua estratégia, considerando as estratégias adotadas pelos demais jogadores; ou seja, as estratégias geraram vantagens a todo o coletivo de jogadores. Se aplicarmos isso à colaboração premiada, perceberemos que o Equilíbrio de Nash ocorre justamente enquanto nenhum membro da organização criminosa colabora com a investigação.

Segundo BOTTINO (2016, p. 373-374), os custos da opção por colaborar são: a) a renúncia ao silêncio e ao direito de não autoincriminaçãa $0^{43}$, b) a incerteza quanto à homologação do acordo. A esses custos, adiciona-se outro, não citado pelo autor: o abandono da prática criminosa e os benefícios a ela inerentes. Este talvez seja o custo mais expressivo a ser suportado pelo colaborador em termos econômicos. Na "Operação Lava-Jato", somente os crimes já denunciados envolveram o pagamento de propinas na faixa de $\mathrm{R} \$ 6,4$ bilhões de reais ${ }^{44}$. A atividade criminosa, dentro de tais organizações, revelou-se lucrativa e com um custo quase mínimo. Conforme exposto anteriormente, a colaboração premiada é utilizada em razão da incapacidade de o Estado investigar tais crimes e obter condenações por outros meios. Portanto, colaborar e abandonar a prática criminosa

42 A cooperação traz elementos de sofisticação à teoria dos jogos, uma vez que o jogador deve considerar não mais apenas sua estratégia individual, mas se comportar de maneira compatível com a estratégia coletiva de maximização das vantagens.

43 Nesse sentido, o direito norte-americano oferece opção interessante. Em alguns estados, admite-se a "Alford Guilty Plea", em que o acusado transige e aceita ser submetido à pena, sem que para isso tenha que confessar ou renunciar ao direito ao silêncio. Trata-se de forma de reduzir os custos de manter acordo. No caso brasileiro, como já frisado, o art. $4^{\circ}, \S 14$, exige expressamente a renúncia ao direito ao silêncio.

44 Dados extraídos do portal da Operação Lava-Jato: http://lavajato.mpf.mp.br/ atuacao-na-1a-instancia/resultados/a-lava-jato-em-numeros. Acesso em $18 / 09 / 2017$. 
constitui escolha extremamente onerosa para o indivíduo, do ponto de vista estritamente econômico.

Já a utilidade que vem da colaboração consiste em uma diminuição da pena. Todavia, colaborar equivale a cambiar uma punição incerta, que depende do poder de investigação do Estado (manifestamente fracassado) por uma punição certa, embora reduzida ${ }^{45}$. Nos termos do art. $4^{\circ}, \S 4^{\circ}$ da Lei $\mathrm{n}^{0} 12.850 / 2013$, a denúncia pode deixar de ser oferecida para o primeiro membro que colaborar, desde que não seja o líder da organização criminosa. Este constitui a vantagem máxima que pode advir do acordo. Em seguida, as informações vão se tornando menos úteis às investigações, fazendo com que os prêmios oferecidos sejam inversamente proporcionais ao número de colaboradores ${ }^{46}$.

Portanto, medindo-se a vantagem da colaboração em função do número de colaboradores, a melhor representação gráfica seria uma curva descendente. Enquanto ninguém colabora, estamos em um Equilíbrio de Nash: evita-se que a acusação descubra qualquer prova, enquanto a atividade criminosa e seu proveito são mantidos. A primeira colaboração atinge um alto nível de utilidade, enquanto da segunda em diante a utilidade é cada vez menor, tendente a zero.

Observe-se que após a primeira colaboração por um dos membros da organização criminosa passa a ser vantajoso colaborar, embora com

45 Podemos citar o seguinte exemplo. A pena prevista para o crime de organização criminosa é de 3 a 8 anos de reclusão, enquanto o benefício comum pela colaboração premiada, segundo a lei, é uma redução de até $2 / 3$ da pena. Suponha que o agente tenha $25 \%$ de chance de ser condenado a 8 anos de prisão, tendo em vista a ineficácia do órgão de investigação. Tal probabilidade equivale a um custo de 2 anos. Colaborando, o agente obtém uma redução de $2 / 3$, sendo condenado a uma pena de 5 anos e 4 meses. A princípio, pode parecer que teve um benefício de 2 anos e 8 meses. Todavia, considerando a remota possibilidade de punição, o custo de persistir na prática criminosa era de apenas 2 anos, enquanto o custo de colaborar foi de 5 anos e 4 meses. Obviamente, tal percentual é hipotética, sendo praticamente impossível mensurar a eficácia dos órgãos de investigação. Todavia, o exemplo serve para demonstrar que a aparente utilidade de um acordo de colaboração nem sempre se verifica.

46 Nos termos do art. $4^{\circ}, \S \S 1^{\circ}$ e $2^{\circ}$ da Lei $n^{\circ} 12.850 / 2013$, a eficácia da colaboração e as circunstâncias pessoais serão o parâmetro para a extensão do prêmio. Quanto mais informações a acusação já detiver, menos eficazes serão as novas informações prestadas, fazendo com que a vantagem seja cada vez menor. 
prêmios menores. Posteriormente, a colaboração deixa de ser vantajosa, uma vez que os prêmios passam a ser muito pequenos. Nesse ponto, até mesmo a acusação deixa de oferecer acordos, pois já possui as informações necessárias para a persecução penal.

BOTTINO (2016, p. 380-382) defende que a colaboração, por se tratar de uma decisão informada e assistida por advogados, deve ser considerada uma escolha racional, dentre as vantagens ao alcance do agente. Não se pode concordar com o argumento do autor. Tratando-se de jogo não simultâneo e cooperativo, que permite a combinação de estratégias coletivas, o Equilíbrio de Nash encontra-se no ponto onde nenhum membro da organização firma acordo de colaboração premiada. A opção por colaborar revela-se como uma estratégia dominada, com retornos menores do que a opção por não colaborar. Tampouco pode-se afirmar que existiria outro Equilíbrio de Nash quando todos os membros colaboram (equilíbrio de estratégias dominadas), uma vez que a vantagem de colaborar é inversamente proporcional ao número de colaboradores e tende a zero.

Os instrumentos negociais no direito brasileiro não se resumem à colaboração premiada. Os juizados especiais criminais, previstos no art. 98, inciso I, da Constituição Federal, foram criados com a finalidade de obter consensualmente a solução de controvérsias penais em casos de certas infrações, evitando pena privativa de liberdade ${ }^{47}$.

Tampouco a análise econômica de tais mecanismos é novidade no direito comparado. Na Itália é comum o estudo da cláusula de nolo contendere (BITTAR, 2011, p. 12-24), enquanto que no sistema anglosaxônico há ampla difusão de modelos para explicação do guilty plea e plea bargaining. O modelo de Rachlinski para análise econômica do processo é utilizado por ULEN e MCADAMS (2008, p. 29-30) para alcançar conclusão semelhante à que foi exposta nesse trabalho: os réus, pelo modelo racional de aversão às perdas, deveriam optar por ir a julgamento em vez de aceitar a punição certa em decorrência de plea bargaining.

47 Na realidade, o Brasil instaurou mecanismos negociais como a transação penal, por exemplo, mas manteve-se apartado tanto do guilty plea quanto do plea bargaining, pois a transação é mais que uma confissão e menos que um amplo acordo sobre a qualificação do crime e a pena. O Ministério Público continua vinculado ao princípio da legalidade processual e à obrigatoriedade da ação penal. 
Contudo, se o Equilíbrio de Nash consiste na ausência de colaboração premiada, como explicar a difusão do instituto no atual cenário brasileiro? Da mesma forma, BIRKE (1999, p. 207) questiona como é possível que mais de $90 \%$ dos casos norte-americanos à época fossem resolvidos por plea bargaining se o natural seria o indivíduo prosseguir a julgamento.

A resposta mais plausível às duas perguntas é oferecida por BIRKE (1999, p. 247-250): não são as propostas do acusador que são muito irresistíveis. Pelo contrário, os réus ou investigados estão cometendo erros sistemáticos e poderiam obter maiores vantagens rejeitando peremptoriamente os acordos oferecidos pelo órgão de acusação ${ }^{48}$. A conclusão apresentada pelo autor não corresponde de maneira plena à aplicação da colaboração em nosso sistema processual. Deve-se considerar que as absolvições estão se tornando cada vez menos frequentes com o avanço das operações de combate à corrupção, o que aumentaria de maneira substancial o custo da decisão de não colaborar. Não obstante, ainda se verifica que a decisão de colaborar é tomada mediante a incidência de atalhos de racionalidade e não propriamente pelo cálculo de utilidade.

\subsection{OS DESVIOS DE RACIONALIDADE DO ACORDO}

Como demonstrado nos tópicos anteriores, o nosso sistema penal é ineficiente. A deficiência de outros meios de prova para investigar a criminalidade organizada diminui a probabilidade de punição. Dessa forma, o equilíbrio da ausência de colaboração é ainda mais evidente. De fato, a Justiça Criminal seria eficiente quando o acusado culpado tende a aceitar acordos (plea bargaining) por saber que há alta probabilidade de ser celeremente condenado (GIVATI, 2011, p. 20-21). Todavia, tal pressuposto é inaplicável a nossa realidade, porque a celeridade processual é considerada apenas limiar teórico em nosso sistema.

48 ULEN e MCADAMS (2008, p. 13) demonstram que a doutrina explicita ainda mais a situação, afirmando que existem vários vieses cognitivos e heurísticas que impedem os réus de tomarem decisões que maximizariam suas vantagens e utilidades. 
Existe claro incentivo à colaboração em nosso sistema: saber que outro membro da organização criminosa aceitou proposta de acordo. O vislumbre da possível persecução criminal tornada factível por informações do primeiro colaborador aumenta os custos da manutenção da prática criminosa, gerando efeito de adesão em massa a novos acordos ${ }^{49}$. O Efeito Adesão, também conhecido como Efeito de Manada, ajuda a explicar porque novos acordos continuam sendo feitos de maneira sistemática.

Todavia, o Efeito Adesão, embora relevante, não explica a razão pela qual o primeiro colaborador opta pelo acordo. Há relevante e visível quebra de equilíbrio, nos moldes propostos pela teoria neoclássica, que não se explica nos termos da racionalidade pura e simples, já que os benefícios de prosseguir na prática criminosa seriam bem maiores. Outrossim, o Efeito Adesão é insuficiente para explicar o surgimento constante de novos acordos, mesmo após tanto tempo, principalmente considerando que os prêmios derivados do acordo são decrescentes e tendentes à zero.

Nesse sentido, as heurísticas demonstradas pela economia behaviorista oferecem resposta adequada para o fenômeno da proliferação irracional da colaboração.

O primeiro elemento de destaque é a assimetria de informações entre acusação e defesa. Como a acusação não tem o dever de expor as provas em seu poder e o alcance das evidências absolutórias que eventualmente venha a ter acesso, como sói acontecer em determinadas hipóteses no direito norte-americano com a chamada Brady Rule ${ }^{50}$, o investigado não tem as mesmas condições de sopesar racionalmente os custos e benefícios de celebrar acordo. Em razão da assimetria de informações,

49 O Efeito Adesão, embora possa ser motivado pelo cálculo utilitário como demonstrado acima, apresenta um viés muito mais psicológico e comportamental do que aparenta. Há uma tendência de se fazer algo porque muitas outras pessoas assim o fazem. AGUIAR, FONSECA e TABAK (2015, p. 26) demonstram como esse efeito possibilitou o desenrolar da Operação Mãos Limpas, na Itália, e atualmente é presente na condução da Operação Lava Jato.

50 O dever de abertura das evidências não é inédito muito menos implausível. No direito norte-americano, a Brady Rule demanda que a acusação disponibilize para a defesa quaisquer evidências absolutórias que eventualmente tenha em seu poder, como forma de equilibrar a assimetria de informações inerente ao processo (PETEGORSKY, 2013, p. 3604-3605; DOUGLASS, 2007, p. 582). 
as decisões serão enviesadas em determinados sentidos demonstrados pela economia behaviorista.

No Brasil, não é arriscado dizer que imperava o entendimento de que a impunidade para crimes de corrupção era a regra, até o caso do Mensalão (AGUIAR, FONSECA, TABAK, 2015, p. 32). O trauma causado pelo caso demonstra seu armazenamento na memória coletiva e sua fácil lembrança quando se trata de crimes de corrupção.

Facilmente aplicável à esta situação a heurística da disponibilidade, já exposta. Aliás, se uma memorável queda de avião é trazida à memória com facilidade, com mais razão um processo criminal noticiado durante anos. A situação recente e traumática de condenação da criminalidade de colarinho branco é facilmente lembrada, induzindo comportamentos favoráveis à colaboração por simples medo de uma condenação equivalente àquela presa na memória. Portanto, muitos acusados ou investigados na Operação Lava Jato vieram buscar a acusação para colaborar ainda que sequer tivessem sido presos (AGUIAR, FONSECA, TABAK, 2015, p. 34).

Sobejamente relevante para a manutenção do viés da disponibilidade é o constante incremento da visibilidade midiática da Operação Lava Jato (MENDES, BARBOSA, 2016, p. 73). Cada vez mais operações são deflagradas e ainda mais acordos de colaboração firmados, incrementando o Efeito Adesão e os eventos memoráveis. O resultado é a manutenção de número crescente de colaboradores, ignorando a sua utilidade tendente a zero.

A assimetria de informações inclina o indivíduo em direção ao otimismo e à ilusão de controle. É inegável que a colaboração, por seu aspecto alegadamente consensual, aparenta maior possibilidade de controle, parecendo ao colaborador que se encontra em melhor situação do que estaria sendo submetido como réu a um processo penal.

O Ministério Público Federal, obviamente, observa a propensão dos acusados a aceitar acordos "especiais" ou "personalizados", oferecendo no âmbito da Operação Lava Jato propostas com prêmios que estão fora dos limites legais, como redução da pena de multa, suspensão dos procedimentos e até mesmo benefícios de execução da pena que ainda não existe (CANOTILHO, BRANDÃO, 2017, p. 155-160). A interpretação é lastreada na máxima a maiori, ad minus (o que é válido para o mais, deve necessariamente valer para o menos), vale dizer, se é possível o acordo 
de colaboração premiada tendo como prêmio o perdão judicial ou acordo de imunidade (o mais), seria possível o menos, que é a redução acima da fração máxima de 2/3 da Lei 12.850/2013 (SILVA, 2017, p. 298-299).

Essas razões reforçam ainda mais a concepção de que a colaboração premiada passou a ser a regra para determinado tipo de criminalidade. Conforme os dados atualizados até 31 de agosto de 2017, apenas em primeira instância foram firmados 158 acordos com pessoas físicas ${ }^{51}$.

Igualmente importante se demonstra a decretação de prisão preventiva do investigado ou acusado. Tradicionalmente, a prisão é entendida como um custo a ser suportado pelo acusado que não colabora, enquanto a liberdade é vantagem a ser obtida (AGUIAR, FONSECA, TABAK, 2015, p. 28-30). Todavia, os efeitos psicológicos da prisão preventiva dificultam a crença na possibilidade de escolhas racionais (sob a ótica do custo-benefício) para preso preventivo (SANGUINE, 2014, p. 22-26). A liberdade provisória não deve ser analisada como vantagem a ser obtida por meio da colaboração, mas como direito constitucionalmente assegurado sempre que ausentes indícios de materialidade e autoria e os pressupostos da medida. A prisão é utilizada como indutora de heurísticas e como modo de turvar e enviesar a racionalidade em favor do acordo de colaboração.

Sob o viés dos descontos hiperbólicos, o oferecimento da liberdade provisória como decorrência da colaboração é a indução de um retorno imediato quase irresistível ao acusado. Ele se vê na possibilidade de obter um prêmio, evitar o processo e ser libertado imediatamente. Por essa razão, aceita os benefícios imediatos, ainda que a opção por ser processado pudesse oferecer retornos maiores a longo prazo.

Todavia, a função mais importante da prisão preventiva constitui na alteração da perspectiva do colaborador, nos moldes da teoria da perspectiva exposta por KAHNEMAN (2011, p. 218-219). Um indivíduo preso possui a tendência de optar pela colaboração ainda que os prêmios oferecidos sejam ínfimos, uma vez que a simples perspectiva de ser libertado da prisão preventiva constitui uma vantagem, naquele momento, superior a quaisquer custos. Trata-se de um nível de adaptação completamente diverso daquele do colaborador solto. Da mesma forma, o indivíduo preso

51 Dados disponíveis em: http://lavajato.mpf.mp.br/atuacao-na-1a-instancia/ resultados/a-lava-jato-em-numeros. Acesso em 20/09/2017. 
possui maior tendência a aceitar quaisquer acordos, pelo simples princípio comportamental de aversão às perdas ${ }^{52}$. Não à toa, a doutrina revela sua desconfiança da prisão preventiva como forma de obter acordos de colaboração nas investigações atuais (AIRES, FERNANDES, 2017, p. 278-279).

Ao analisar o equilíbrio entre perdas e ganhos, SUNSTEIN e THALER (2008, p. 33-34) indicam experimentos de aversão às perdas segundo os quais o valor atribuído pelo indivíduo a algo que ele já tem chega a duas vezes mais do que o valor real ${ }^{53}$. Poder-se-ia inferir, analogicamente, que os prêmios oferecidos ao acusado solto deveriam ser pelo menos duas vezes maiores do que os prêmios aceitos pelos acusados presos. Fácil compreender a preferência por firmar acordo com acusados presos.

Os mesmos autores destacam que indicar determinada opção como "padrão" faz com que a ela se direcionem as preferências da maior parte dos indivíduos ${ }^{54}$. O padrão de colaboração da Operação Lava Jato, bem como a sua visibilidade como meio comum de obtenção da liberdade provisória para réus presos, justifica a opção pelo acordo.

Todas as condições acima expostas, além de tantas outras, institucionais ou não, contribuíram para a proliferação dos acordos de colaboração, ainda que esta opção não pudesse ser considerada a mais racional. A colaboração premiada tende a chegar em um nível de esgotamento, em

52 Nesse âmbito, a aversão às perdas exposta por KAHNEMAN (2011, p. 218219) pode ser analisada do ponto de vista individual ou comparativo. Do ponto de vista individual, o acusado preso que decide por não colaborar perde a imediata possibilidade de liberdade provisória; portanto, adota posição de aversão à perda e favorável à colaboração. Comparativamente, por outro lado, o acusado solto apresentaria maior resistência ao acordo, pois seria avesso a sofrer os custos da colaboração imediatamente.

53 O experimento descrito por SUNSTEIN e THALER (2008, p. 33-34) consistia na distribuição de canecas entre os alunos de uma Turma, deixando poucos alunos sem receber. Estes, então, deveriam negociar a compra da caneca com os alunos que as receberam. A conclusão alcançada é de que os alunos estavam dispostos a pagar apenas metade daquilo que os outros alunos esperavam receber.

54 Segundo SUNSTEIN e THALER (2008, p. 35), a visibilidade da opção como padrão funciona como um "empurrão" para a conduta individual, em razão do viés da manutenção do status quo. Nesse viés, adotar posturas ou estratégias arriscadas funciona de maneira contrária às estratégias comportamentais da maioria, que preferem adotar o "padrão". Há uma certa semelhança, neste ponto, quanto ao Efeito Adesão. 
que a utilidade de novas informações é ínfima e o prêmio oferecido tende a zero. Em outubro de 2016, a Polícia Federal do Paraná já demonstrou a desnecessidade de novos acordos de colaboração premiada ${ }^{55}$. À época, em primeira instância haviam sido feitos 66 acordos de colaboração premiada (SILVA, 2017, p. 292-293). Não obstante, continuaram sendo firmados mais e mais acordos. A cifra atualizada está em 158 acordos $^{56}$. Mesmo após o suposto esgotamento, o número de acordos mais que dobrou. Se os acordos continuam sendo desvantajosos para os colaboradores, persiste a seguinte pergunta: por que o órgão de acusação continua propondo os acordos?

A proposta de acordo pelo Ministério Público Federal sempre leva em conta os cálculos de law and economics. A acusação continua propondo acordos com prêmios altos e desproporcionais à utilidade das informações, porque tornou-se mais interessante repatriar ativos como condição do acordo de colaboração do que continuar obtendo provas (SILVA, 2017, p. 305). Com base no cálculo de BECKER (1974, p. 1214), a colaboração tornou-se um meio transverso de aplicar uma elevada "pena de multa” de natureza atípica.

Denota-se um discurso utilitário-economicista como tônica do processo penal relativo aos crimes de corrupção, que leva os órgãos de persecução e o Poder Judiciário a buscarem um resultado patrimonial no processo (mercantilização processual), atropelando-se a legalidade penal - caracterizada por regras imperativas e de aplicação obrigatória - e tornando a liberdade objeto de compra pelo colaborador.

A mercantilização do processo penal mina valores constitucionais, como a imparcialidade judicial e o dever do Ministério Público, encorajando os participantes do processo a celebrar colaborações conduzidas por interesses partidários (BROWN, 2016, p. 92-94).

Deve-se atentar ao fato de que os órgãos acusatórios não são alheios à existência de heurísticas e vieses cognitivos que afetam os comportamentos dos acusados. Pelo contrário, o uso da prisão preventiva

55 MEGALEI, Bela. PF se opõe a novas delações premiadas na Lava Jato. São Paulo: Folha de São Paulo. 04 de Outubro de 2016. Disponível em: < http:// www1.folha.uol.com.br/poder/2016/10/1819588-pf-se-opoe-a-novas-delacoes-premiadas-na-lava-jato.shtml>. Acesso em: 07 jan. 2017.

56 Dados disponíveis em: http://lavajato.mpf.mp.br/atuacao-na-1a-instancia/ resultados/a-lava-jato-em-numeros. Acesso em 20/09/2017. 
como "incentivo" à colaboração demonstra o domínio dos instrumentos da economia comportamental. ULEN e MCADAMS (2008, p. 30) demonstram que a acusação está ciente dos vieses e utilizam-nos para influenciar suas decisões no processo penal ${ }^{57}$. A possibilidade de a acusação manipular ou induzir vieses cognitivos não é alvissareira, contando com inúmeros estudos no sistema de common law.

Não é de se estranhar, também, que os próprios acusados sobrestimem a pena em momentos de crise, com base nos estudos de ULEN e MCADAMS (2008, p. 29-30). Muito menos estranho é que o órgão acusatório se aproveite do momento de crise política e ofereça mais acordos, induzindo o incremento do viés da disponibilidade. Seja pela assimetria de informações, seja pela utilização da prisão preventiva como forma de alteração da perspectiva do acusado ou, até mesmo, pelas múltiplas relações entre estes, o acordo de colaboração revela-se cada vez mais irracional e desvantajoso para o acusado.

Criou-se um cenário em que a colaboração não é mais tratada nos limites da legalidade, mas conduzida de forma discricionária como trunfo para que os demais investigados também sejam levados a fazer acordos e expandir o alcance da "rede de criminosos" à disposição da acusação. A manipulação de desvios cognitivos aliada a prisões preventivas por longos períodos ameaça elemento essencial ao acordo, que é a livre escolha dos colaboradores, mediante a extrapolação dos lindes legais do acordo e a criação de condicionantes ao puro arbítrio da autoridade (MORAIS, BONACCORSI, 2016, p. 100-101).

\section{Conclusões}

O objetivo deste trabalho foi questionar se a decisão de colaborar com a justiça constitui ou não escolha economicamente racional e eficiente do ponto de vista do acusado colaborador.

57 Os autores citam o exemplo da fraude em seguradoras. Os investidores subestimam o risco de fraudes nos momentos em que o mercado está em bom desempenho. Dessa forma, a acusação pode equilibrar a situação promovendo mais acusações durante momentos de bom desempenho, promovendo exemplos vívidos de fraude que podem induzir uma heurística da disponibilidade (ULEN, MCADAMS, 2008). 
Para este objetivo, foi demonstrado, primeiramente, o que se entende pelo instituto e a forma como foi transplantado ao contexto brasileiro. Nesse sentido, especial atenção à dependência instaurada entre poder de investigação e instrumentos colaborativos, ressaltando a dificuldade de o Estado proceder à prova dos fatos por outros meios.

Em seguida, foram trazidos alguns dos pilares da análise econômica neoclássica e as críticas feitas pela corrente comportamental, ressaltando a insuficiência do critério da pura utilidade e racionalidade para explicar o comportamento econômico dos indivíduos. Da mesma forma, foi demonstrado que, pelos pressupostos da economia neoclássica e da teoria dos jogos, o equilíbrio econômico na colaboração premiada, do ponto de vista dos colaboradores, seria a coordenação de estratégias para a rejeição dos acordos. Ademais, foi assentado que a maior vantagem que o acordo oferece é para o primeiro colaborador; em seguida, a utilidade é decrescente e tendente a zero.

Por fim, buscou-se uma explicação para a proliferação dos acordos nos pressupostos da economia comportamental. Alcançamos a conclusão de que os acordos de colaboração são erros sistemáticos realizados pelos colaboradores, motivados principalmente pela assimetria de informações (e, em consequência, vieses cognitivos) e pelo uso da prisão preventiva como mecanismo de alteração da perspectiva econômica.

$\mathrm{Na}$ realidade, o uso irracional da colaboração oferece diversos riscos. A mercantilização do processo penal, voltado apenas à repatriação de ativos e aplicação transversa da pena de multa, mina o primado da legalidade, possibilitando a compra da liberdade e acelerando o processo de seletividade do sistema criminal. Ademais, o uso da prisão preventiva como incentivo à colaboração traz efeitos nefastos a longo prazo, que não podem ser ignorados pela pressão momentânea de apresentação de resultados.

O que se concluiu, ao final da análise dos pressupostos teóricos e de sua incidência prática, é que a decisão de colaborar com as investigações é economicamente irracional e ineficaz, sendo possível apenas em razão de desvios cognitivos que manipulam o próprio conceito de voluntariedade do acordo.

Verificado o uso irracional e contrário à eficiência econômica, nada mais natural que o direito interfira para equilibrar a atuação dos agentes de acordo com os valores constitucionalmente protegidos (PICKER, 1994, p. 
20). A melhor forma de corrigir os vícios de racionalidade da colaboração, do ponto de vista do colaborador, seria aprimorando o sistema de justiça: incrementar a celeridade do processo e desenvolver instrumentos de investigação que independam do auxílio da própria organização criminosa.

Além disso, restringir o uso da prisão preventiva às hipóteses estritamente necessárias é uma demanda não apenas no âmbito da colaboração premiada, mas de todo o sistema de justiça, que apresenta elevados percentuais de presos provisórios em situações precárias e que podem, inclusive, ser absolvidos posteriormente.

Por fim, a assimetria de informações pode e deve ser corrigida com instrumentos já existentes. No sistema norte-americano, por exemplo, a acusação possui o dever de revelar as evidências absolutórias ou exculpatórias que estejam em seu poder, sob a égide da chamada Brady Rule. A introdução de regra semelhante poderia contribuir para uma diminuição da assimetria de informações e possibilitar que o acusado analise de maneira coerente e informada os custos e benefícios da colaboração.

O objetivo da pesquisa não é condenar a possibilidade de uso da colaboração premiada. Pelo contrário, sua aplicação possibilitou avanços em outros países e vem contribuindo para uma mudança de cultura punitiva no sistema brasileiro, antes focado somente em crimes patrimoniais e tráfico de drogas. Todavia, a utilização deve ocorrer de maneira racional e coerente com o princípio da legalidade, possibilitando decisões informadas e marcadas pela boa-fé objetiva, principalmente na atuação do ente estatal que oferece o acordo.

\section{REFERÊNCIAS}

AGUIAR, Julio César de. FONSECA, Cibele Benevides Guedes da. TABAK, Benjamin Miranda. A Colaboração Premiada Compensa? Brasília: Núcleo de Estudos e Pesquisas/ CONLEG/Senado, agosto/2015 (Texto para Discussão no 181). Disponível em: www.senado.leg.br/estudos. Acesso em: 22 set. 2017.

AGUIAR, Bernardo Augusto Teixeira de. A análise econômica do direito: aspectos gerais. Âmbito Jurídico, Rio Grande, v. XVI, n. 110, mar. 2013. Disponível em: $<$ http://www.ambito-juridico.com.br/site/index.php/?n_link=revista_artigos_leitura\&artigo_id=13019\&revista_caderno=27>. Acesso em: 22 set.2017.

AIRES, Murilo T.; FERNANDES, Fernando A. A colaboração premiada como instrumento de política criminal: a tensão em relação às garantias fundamentais 
do réu colaborador. Revista Brasileira de Direito Processual Penal, Porto Alegre, v. 3, n. 1, p. 253-284, jan./abr. 2017. https://doi.org/10.22197/rbdpp.v3i1.46.

AMARAL, Augusto J.; GLOECKNER, Ricardo J. A delação nos sistemas punitivos contemporâneos. Revista Brasileira de Ciências Criminais, São Paulo, ano 25, v. 128, p. 65-89, fev. 2017.

BAR-GILL, Oren; HAREL, Alon. Crime Rates and Expected Sanctions: The Economics of Deterrence Revisited, J. LEGAL STUD,vol. 30, nº 2, p. 485-501, jun./2001. https://doi.org/10.1086/322055.

BAR-GILL, Oren. EPSTEIN, Richard. Consumer Contracts: Behavioral Economics vs. Neoclassical Economics. Law \& Economics Research Paper Series, Working Paper No. 07-17, New York, 2007.

BECKER, Gary S. Crime and Punishment: an economic approach. In: BECKER, Gary S.; LANDES, William M. (Eds.) Essays in the Economics of crime and Punishment. [S.1.]: National of Economic Research, 1974. p. 1-54. Disponível em: <http:// www.nber.org/chapters/c3625.pdf>. Acesso em: 22set. 2017.

BELLI, Benoni. Violência, Tolerância Zero e Democracia no Brasil: Paradoxos da Década de 90. Tese (Doutorado em Sociologia) - UnB, Brasília, 2003.

BIRKE, Richard. Reconciling Loss Aversion and Guilty Pleas, Utah Law Rev., Salt Lake City, p. 205-254, 1999.

BITTAR, Walter Barbosa. Delação Premiada: Direito Estrangeiro, Doutrina e Jurisprudência. $2^{\mathrm{a}}$ Ed. Rio de Janeiro: Lumen Juris, 2011.

BOTTINO, Thiago. Colaboração Premiada e Incentivos à Cooperação no Processo Penal: uma análise crítica dos acordos firmados na Operação Lava Jato. Revista Brasileira de Ciências Criminais, São Paulo, vol. 122, pags. 359-390, set./out. 2016.

BRENNER, Geraldo. Entendendo o Comportamento Criminoso: educação, ensino de valores morais e a necessidade de coibir o comportamento criminoso: uma contribuição da teoria econômica e um recado para nossas autoridades. Porto Alegre: AGE, 2009.

BRITO, Michelle Barbosa de. Delação Premiada e Decisão Penal: da eficiência à integridade. Belo Horizonte: Editora D’Plácido, 2017.

BROWN, Darryl. K. Free Market Criminal Justice: How Democracy and Laissez Faire Undermine the Rule of Law. New York: Oxford. 2016. https://doi.org/10.1093/ acprof:oso/9780190457877.001.0001.

CALABRESI, Guido. The Cost of Accidents: a legal and economic analysis. New Haven: Yale University Press, 2008.

CANOTILHO, J. J. Gomes; BRANDÃO, Nuno. Colaboração premiada: reflexões críticas sobre os acordos fundantes da Operação Lava Jato. Revista Brasileira de Ciências Criminais, São Paulo, v. 133, ano 25, p. 133-171, jul. 2017. 
CHOUKR, Fauzi Hassan. Processo Penal de Emergência. Rio de Janeiro: Lumen Juris, 2002.

COOTER, Robert. ULEN, Thomas. Law and Economics. $6^{\mathrm{a}}$ Ed. Boston: AddisonWesley, 2012.

COSTA, Leonardo Dantas. Delação Premiada. A atuação do Estado e a Relevância da Voluntariedade do Colaborador com a Justiça. Curitiba: Juruá, 2017.

DOUGLASS, John G. Can Prosecutors Bluff? Brady v. Maryland and Plea Bargaining. Case Western Reserved Law Review, vol. 57, p. 581-592, 2007. Disponível em: http://scholarship.richmond.edu/cgi/viewcontent.cgi?article=1083\&context=law-faculty-publications. Acesso em: 22 set. 2017.

FAURE, Michael. LUTH, Hanneke. Behavioural Economics in Unfair Contract Terms: Cautions and Considerations. Journal of Consumer Policy, vol. 34, $\mathrm{n}^{\mathrm{o}} 3$, pags. 337-358, 2011. https://doi.org/10.1007/s10603-011-9162-9.

FIANI, Ronaldo. Teoria dos Jogos. $3^{\mathrm{a}}$ Ed. Rio de Janeiro: Elsevier, 2009.

FONSECA, Cibele B. G. Colaboração premiada. Belo Horizonte: Del Rey, 2017.

GAROUPA, Nuno. Behavioral Economic Analysis of Crime: A Critical Review, European J. Law \& Econ., vol. 15, p. 5-15, 2003.

GIVATI, Yehonatan. The Comparative Law and Economics of Plea Bargaining: Theory and Evidence. Discussion Paper $n^{\circ} 39$, Harvard Law School, Cambridge, MA 02138, 2011. Disponível em: <http://www.law.harvard.edu/programs/ olin_center/fellows_papers/pdf/Givati_39.pdf.>Acesso em: 22 set.2017.https:// doi.org/10.2139/ssrn.1889316.

GONÇALVES, Carlos Eduardo. A Análise Econômica do Direito Penal. In: ÁVILA, Gustavo Noronha de. MELLO, Marília Montenegro Pessoa de. VIANNA, Tulio Lima. Criminologias e política criminal. Florianópolis: CONPEDI, 2015, p. 67-90.

HALBERSBERG, Yoed. GUTTEL, Ehud. Behavioral Economics and Tort Law. Hebrew University of Jerusalem Legal Studies Research, paper series $\mathrm{n}^{\circ} 2-15$. Jerusalem, 2015.

JOLLS, Christine. On Law Enforcement With Boundedly Rational Actors. Discussion Paper $n^{\circ}$ 494. Harvard Law School, Cambridge, MA 02138, 2004. https:// doi.org/10.2139/ssrn.631222.

KAHNEMANN, Daniel. Thinking, Fast and Slow. New York: Farrar, Straus and Giroux, 2011. https://doi.org/10.4324/9781912453207.

KOROBKIN, Russell. ULEN, Thomas. Law and Behavioral Science: Removing the Rationality Assumption from Law and Economics. California Law Review, Berkeley, vol. 88, n 4, Jul. 2000. https://doi.org/10.2307/3481255. 
KURAN, Timor. SUNSTEIN, Cass. Availability Cascades and Risk Regulation. Stanford Law Review, Stanford vol. 51, no 4, pags. 683-768, abril 1999. https:// doi.org/10.2307/1229439.

LIMA, Renato Brasileiro de. Curso de Processo Penal. Niterói/RJ: Impetus, 2013.

MCNUTT, Paddy. The Economics of Public Choice. Second Edition. Northampton: Edward Elgar, 2002.

MENDES, Soraia da Rosa; BARBOSA, Kássia Cristina de Souza. Anotações sobre o requisito da voluntariedade e o papel do/a juiz/a em acordos de colaboração premiada envolvendo investigados/as e /ou réus/és presos/as provisoriamente. In: MENDES, Soraia da Rosa (org.). A delação/colaboração premiada em perspectiva. Brasília: IDP. 2016.

MORAIS, Flaviane de Magalhães B. B. BONACCORSI, Daniela Villani. A Colaboração por Meio do Acordo de Leniência e Seus Impactos Junto ao Processo Penal Brasileiro: um estado a partir da Operação Lava Jato. Revista Brasileira de Ciências Criminais, São Paulo, vol. 122, pags. 93-113, set./out. 2016.

PEREIRA, Frederico Valdez. Delação Premiada: Legitimidade e Procedimento. $2^{\mathrm{a}}$ Ed. Curitiba: Juruá, 2013.

PETEGORSKY, Michael Nasser. Plea Bargaining in the Dark: The Duty to Disclose Exculpatory Brady Evidence During Plea Bargaining, Fordham L. Rev., vol. 81, p. 3599-3650, 2013. Disponível em: http://ir.lawnet.fordham.edu/flr/vol81/ iss6/13. Acesso em: 22 set. 2017.

PICKER, Randal. An Introduction to Game Theory and the Law. Coase-Sandor Institute for Law \& Economics, Working Paper No. 22, Chicago, 1994.

POSNER, Ericc. Análise econômica do direito contratual: sucesso ou fracasso? São Paulo: Saraiva, 2010.

POSNER, Richard. An Economic Theory of the Criminal Law. Columbia Law Review, New York, vol. 85, nº 6, out. 1985.

ROSA, Alexandre Morais da; LINHARES, José Manuel Aroso. Diálogos com a Law \& Economics. 2. ed. Rio de Janeiro: Lumen Juris, 2011.

SANGUINÉ, Odone. Prisão Cautelar, Medidas Alternativas e Direitos Fundamentais. Rio de Janeiro: Forense, 2014.

SILVA, Marcelo Rodrigues da. A colaboração premiada como terceira via do direito penal no enfrentamento à corrupção administrativa organizada. Revista Brasileira de Direito Processual Penal, Porto Alegre, vol. 3, n. 1, 2017. https://doi. org/10.22197/rbdpp.v3i1.50. 
SUNSTEIN, Cass. THALER, Richard. Nudge: improving decisions about health, wealth and happiness. Yale University Press, 2008. https://doi. org/10.4324/9781912282555.

ULEN, Thomas. MCADAMS, Richard. Behavioral Criminal Law and Economics. John M. Olin Program in Law and Economics, Working Paper No. 440, Chicago, 2008. https://doi.org/10.4337/9781781950210.00021.

WINTER, Harold. The Economics of Crime: an introduction to rational crime analysis. New York: Routledge, 2008. https://doi.org/10.4324/9780203927465.

WRIGHT, Joshua. Behavioral Law And Economics, Paternalism, And Consumer Contracts: An Empirical Perspective. NYU Journal of Law \& Liberty, Vol. 2, No. 3, pp. 470-511, 2007

VASCONCELLOS, Marco Antonio Sandoval de. Economia: micro e macro. $4^{\mathrm{a}}$ Ed. São Paulo: Atlas, 2006.

VASCONCELLOS, Vinicius Gomes de. Barganha e Justiça Criminal Negocial: análise das tendências de expansão dos espaços de consenso no processo penal brasileiro. Dissertação (Mestrado em Direito) - PUC/RS, Porto Alegre/RS, 2014.

VASCONCELLOS, Vinicius Gomes de. Colaboração premiada no processo penal. $1^{\mathrm{a}}$ ed. São Paulo: RT, 2017.

\section{Informações adicionais e declarações dos autores (integridade científica)}

Declaração de conflito de interesses (conflict of interest declaration): o autor confirma que não há conflitos de interesse na realização das pesquisas expostas e na redação deste artigo.

Declaração de autoria e especificação das contribuições (declaration of authorship): todas e somente as pessoas que atendem os requisitos de autoria deste artigo estão listadas como autores; todos os coautores se responsabilizam integralmente por este trabalho em sua totalidade.

Declaração de ineditismo e originalidade (declaration of originality): o autor assegura que o texto aqui publicado não foi divulgado anteriormente em outro meio e que futura republicação somente se realizará com a indicação expressa da referência desta publicação original; também atesta que não há plágio de terceiros ou autoplágio. 


\section{Dados do processo editorial}

(http://www.ibraspp.com.br/revista/index.php/RBDPP/about/editorialPolicies)

- Recebido em: 27/10/2018

Equipe editorial envolvida

- Controle preliminar e verificação de plágio:

- Editor-chefe: 1 (VGV) 28/10/2018

- Avaliação 1: 10/11/2018

- Revisores: 2

- Avaliação 2: 16/11/2018

- Decisão editorial preliminar: 08/12/2018

- Retorno rodada de correções: 17/01/2019

- Decisão editorial final: 18/01/2019

\section{COMO CITAR ESTE ARTIGO:}

KALKMANN, Tiago. Análise econômica da racionalidade do acordo de colaboração premiada. Revista Brasileira de Direito Processual Penal, Porto Alegre, vol. 5, n. 1, p. 469-504, jan./abr. 2019.

https://doi.org/10.22197/rbdpp.v5i1.195

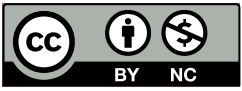

Esta obra está licenciada com uma Licença Creative Commons Atribuição-NãoComercial 4.0 Internacional. 